\title{
HAWKSBILL TURTLES VISIT MOUSTACHED BARBERS: CLEANING SYMBIOSIS BETWEEN ERETMOCHELYS IMBRICATA AND THE SHRIMP STENOPUS HISPIDUS
}

\author{
Ivan Sazima ${ }^{1 *}$, Alice Grossman'2, Cristina Sazima ${ }^{1,3}$
}

Biota Neotropica v4(n1) - http://www.biotaneotropica.org.br/v4n1/pt/abstract?short-communication+BN01504012004

\author{
Date Received 01/21/2004 \\ Revised 02/22/2004 \\ Accepted 03/12/2004
}

\begin{abstract}
1- Departamento de Zoologia e Museu de História Natural, Caixa Postal 6109, Universidade Estadual de Campinas, 13083-970 Campinas, São Paulo, Brazil (http://www.unicamp.br)

*Corresponding author. Tel: + 55-19-3788 7292; fax: +55-19-32893124; e-mail: isazima@unicamp.br

2 - Projeto Tamar/Ibama, Alameda Boldró s/no, 53990-000 Fernando de Noronha, Pernambuco, Brazil

3 - Departamento de Zoologia, Caixa Postal 199, Universidade Estadual Paulista, 13506-900 Rio Claro, São Paulo, Brazil
\end{abstract}

\begin{abstract}
At the oceanic island of Fernando de Noronha, off northeast Brazil, we recorded the hawksbill turtle (Eretmochelys imbricata) visiting cleaning stations tended by the barber pole shrimp (Stenopus hispidus). This seems to be the first record of cleaning symbiosis between marine turtles and shrimps. During their foraging on the reef flat, the turtles regularly visited and posed at the stations. The same stations were visited by a few species of reef fishes, which posed and were cleaned by the shrimps. We suggest that cleaning symbiosis between turtles and shrimps is widespread and went unrecognised due to the superficial resemblance between a resting turtle and a posing and cleaned one. Additionally, we submit a putative origin for the cleaning symbiosis between marine turtles and cleaner shrimps following a few simple behavioural steps.
\end{abstract}

Key words: Marine turtle-cleaner shrimp association, cleaning symbiosis, origin of turtle-shrimp association, reef environment, Equatorial West Atlantic

\section{Resumo}

Nas ilhas oceânicas de Fernando de Noronha, ao largo da costa Nordeste do Brasil, registramos tartarugas-de-pente (Eretmochelys imbricata) visitando estações de limpeza mantidas pelo camarão-palhaço (Stenopus hispidus). Este parece ser o primeiro registro de simbiose de limpeza entre tartarugas marinhas e camarões. Durante o seu forrageamento na planície recifal, as tartarugas visitavam e posavam nas estações regularmente. As mesmas estações eram visitadas por algumas espécies de peixes recifais, que aí posavam e eram limpas pelos camarões. Sugerimos aqui que a simbiose de limpeza entre tartarugas marinhas e camarões seja comum e difundida, porém passa despercebida devido à semelhança superficial entre uma tartaruga que esteja descansando e aquela posando e sendo limpa. Além disso, apresentamos uma origem putativa para a simbiose de limpeza entre tartarugas marinhas e camarões-limpadores, que segue etapas comportamentais relativamente simples.

Palavras-chave:Associação entre tartarugas marinhas e camarões-limpadores, Simbiose de limpeza, origem da associação tartaruga-camarão, ambiente recifal, Atlântico Equatorial Ocidental 


\section{Introduction}

Cleaning symbiosis between two species of marine turtles and several species of reef fishes has been recorded both from the Pacific and the Atlantic (Booth \& Peters, 1972; Smith, 1988; Losey et al., 1994). In this kind of interaction, the cleaner fishes obtain food, and the turtles get rid of the organisms' growth on their shells and/or soft body parts (Smith, 1988; Losey et al., 1994). Cleaning interaction with reef fishes was only recently recorded for the green turtle (Chelonia mydas) at the oceanic islands of Fernando de Noronha Archipelago, Equatorial West Atlantic (Sazima et al., 2004).

To the best of our knowledge, however, no records of this type of interaction have been recorded between sea turtles and cleaner shrimps. This invertebrate cleaner type is known to interact with several reef fish species in the Mediterranean, the Atlantic, and the Pacific (reviews in Limbaugh et al., 1961; Criales \& Corredor, 1977; Van Tassel et al, 1994; Côté, 2000). We report here on cleaning symbiosis between the hawksbill turtle (Eretmochelys imbricata) and the barber pole shrimp (Stenopus hispidus) at the Fernando de Noronha Archipelago, off North-eastern Brazil.

\section{Material and Methods}

The hawksbill turtle-cleaner shrimp symbiosis was recorded at the Fernando de Noronha Archipelago (0350'S, $32^{\circ} 25^{\prime} \mathrm{W}$ ), about $345 \mathrm{~km}$ off NE Brazil (see Maida \& Ferreira, 1997 for map and description). Field study was conducted in November and December 2003 at the Baía do Sueste, on a reef flat composed of sandy bottom interspersed with rocky ledges sparsely to thickly covered by brown foliose algae, red coralline algae and stony corals (see description and illustrations in Maida et al., 1995, 1997; Sanches \& Bellini, 1999). Depth at the observation site ranged up to $4 \mathrm{~m}$ at high tide, and 1.5-2.5 $\mathrm{m}$ at ebb tide.

Hawksbills' foraging and their cleaning by the barber pole shrimps were recorded in seven non-consecutive days while snorkelling (40-90 min each day). During observational sessions of 10-30 min (total observation time $185 \mathrm{~min}$ ) we used focal animal samplings, in which all occurrences of specified actions were recorded (Altmann, 1974; Lehner, 1979). We focused on the postures assumed by the turtle while being cleaned, in order to infer to what body parts the shrimps were possibly nibbling at. Since barber pole shrimps attend their clients from within the recesses of coves or crevices (Limbaugh et al., 1961; Criales \& Corredor, 1977; Humann, 1996), their cleaning behaviour is more difficult to observe than that of cleaner fishes. In all our observations, the turtle's body was partly wedged under rocky ledges on which the stations were located and thus prevented a clear view of the cleaner shrimps. Therefore, most of the cleaners' behaviour was inferred from the turtles' behaviour at the station and the more visible movements the shrimps did at their station while cleaning smaller clients such as reef fishes (Limbaugh et al., 1961 comment on similar hindrances for observing shrimps' cleaning behaviour).

\section{Results}

We found two barber pole shrimp cleaning stations being visited by hawksbill turtles on the reef flat. One of them was tended by an adult shrimp couple (Fig. 1), whereas the other was occupied by a single, supposedly juvenile shrimp. The two stations were on rocky outcrops densely covered by green algae, and adjacent to a sandy patch. The adult shrimps measured about $5 \mathrm{~cm}$ in body length and remained within large crevices under ledges, usually on the ceiling near the entrance (Fig. 2) from where they waved their long white antennae. The juvenile shrimp measured about $3 \mathrm{~cm}$.

Hawksbill turtles spent 3-4 hours foraging and fed on mixed algal turf, an activity interspersed with periods of resting on the bottom or short breathing bouts on the water surface. Along their activity on the reef flat the turtles regularly sought the shrimps' cleaning stations.

The description below is a composite of the two most complete observations, and is representative of all our records of turtles $(n=7)$ on the two cleaning stations. In one of these records the turtle was already posing at the station and left on the observer's approach. The other record included approaching, posing, and leaving, but the view of the turtle's behaviour was somewhat hindered by the observer's position from behind the station.

After foraging for a while, the hawksbill turtle swam directly towards the cleaning station, landed in front of it and adjusted its position to accommodate the left or right portion of its hind-body and limbs under the rocky ledge. Its posture while at the station was very characteristic: its hind limbs were sprawled and the forelimbs were stretched holding its fore body and head elevated. The turtle held this posture for $50-60 \mathrm{sec}$ after which it moved away. While at the shrimp station the turtle remained watchful and prone to flee at an observer's close approach.

Judging from the turtles' posture and their positioning under the ledge, they made available both the limbs (soft parts) and the carapace and plastron (hard parts) to the cleaner shrimps. From what we observed of the shrimps' behaviour while cleaning fishes and the use they make of their delicate, smaller chelae (claws), we presume that they nibbled at the turtles' soft parts, most probably the skin folds and the spaces between the limbs' scales (see Discussion). 


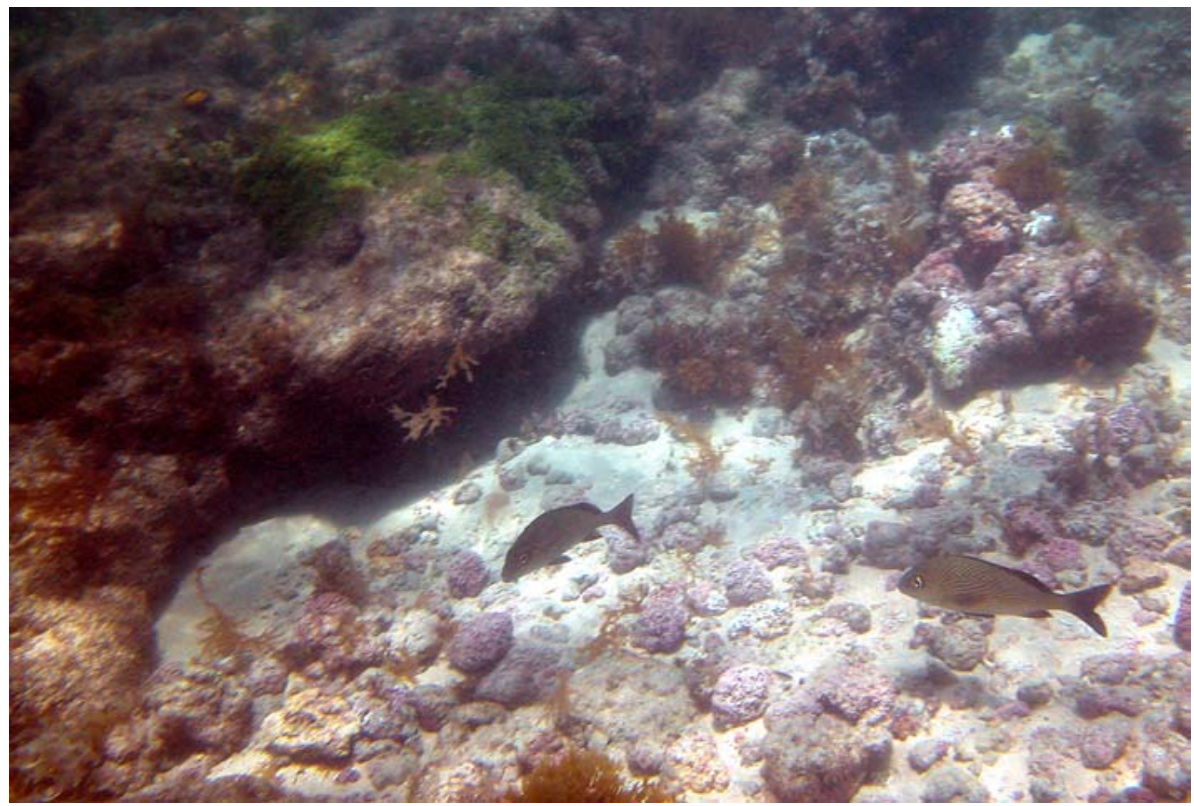

Fig. 1. A cleaning station of the barber pole shrimp (Stenopus hispidus) under a rocky ledge on a reef flat at the Baía do Sueste, Fernando de Noronha Island, off NE Brazil. Two grunt clients (Haemulon parra) are lingering near the station.

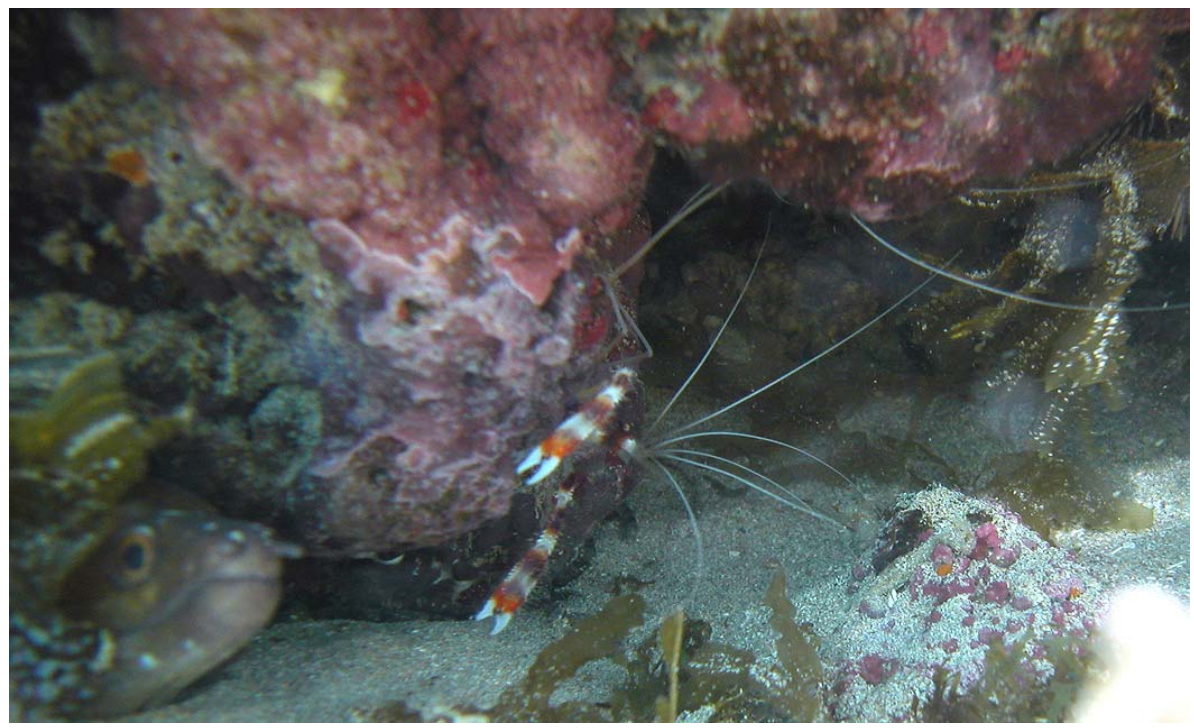

Fig. 2. A couple of barber pole shrimps (Stenopus hispidus) at the cleaning station, the individual in the centre showing off the white long antennae and strong claws. The head of a moray (Gymnothorax miliaris) is visible in the left lower corner. 
We recorded three turtle individuals at the two cleaning stations. The largest individual measured $63.5 \mathrm{~cm} \mathrm{CCL}$ and was recorded twice at the station tended by the shrimp couple. The second one measured $61.5 \mathrm{~cm}$ CCL and was recorded four times at the same station. Both turtles are five-years residents at the study site, the first with 15 records and the second with 23 ones over the period (AG, pers. obs.). The smallest hawksbill measured about $40 \mathrm{~cm} \mathrm{CCL}$ and was recorded only once at the juvenile shrimp cleaning station. We have no previous record of this individual.

After leaving a cleaning station all turtles followed the same path and were found foraging on the reef flat not far from the two cleaning stations. Additional hawksbills were found on the same feeding grounds, and possibly visited the shrimp stations as well.

Three species of reef fishes regularly visited the same stations used by the turtles and were cleaned by the barber pole shrimps: the surgeonfish Acanthurus chirurgus, the grunt Haemulon parra, and the parrotfish Sparisoma axillare.

\section{Discussion}

All hawksbill individuals recorded foraging on the reef flat and posing at the barber pole shrimp cleaning station were juveniles (see Witzell, 1983 for size of adults), although adult males were recorded at the reef flat occasionally (AG, pers. obs.). These findings agree with an 11years study on occurrence of hawksbills and green turtles at the Fernando de Noronha Archipelago (Sanches \& Bellini, 1999).

The posture assumed by the hawksbill turtle while on a cleaner shrimp station differed from the pose the green turtle assumes while being cleaned by small reef fishes (see Booth \& Peters, 1972; Losey et al., 1994 for illustration and description), as the hawksbill rested on the bottom with its fore limbs stretched, the head and fore body elevated.

The narrow spaces between skin folds and limbs' scales probably are unavailable to a medium-sized or even a small cleaner fish (Sazima et al., 2004), as its mouth is larger and thus more 'clumsy' than the delicate lesser claws of a cleaner shrimp. We think this may be one cause for hawksbills seeking cleaning stations tended by barber pole shrimps and manoeuvring as that these body parts became available to the cleaners.

Three cleaner shrimp species are recorded cleaning reef fishes at the Fernando de Noronha Archipelago (Francini-Filho et al., 1999). The barber pole shrimp stands among the largest tropical West Atlantic cleaner shrimps (Limbaugh et al., 1961; Criales \& Corredor, 1977; Humann, 1992) and thus its claws are larger than those of the other shrimps. We think that another cause for hawksbills seek- ing this shrimp is its large size (and thus its relative visibility), besides its large claws probably being able to deliver tactile stimuli perceptible even for the though hide of marine turtles (see Losey, 1993 for proximate causes of cleaning symbiosis).

To date the instances of cleaning symbiosis between marine turtles and cleaning fishes recorded at the Fernando de Noronha Archipelago involve fish species relatively unspecialised as cleaners (Sazima et al., 2004; pers. obs.). This indicates that marine turtles likely are unimportant clients for the relatively specialised fish cleaners such as the french angelfish Pomacanthus paru (Sazima et al., 1999) or the Noronha wrasse Thalassoma noronhanum (FranciniFilho et al., 2000). Indeed, cleaning stations tended by juvenile angelfish and wrasses were found close to the shrimp stations, but not a single cleaning interaction was recorded between turtles and these fish cleaners. This view remains to be tested as more data accumulate on cleaning symbiosis between marine turtles and reef fishes in the Southwest Atlantic (see below).

Although cleaning symbiosis between marine turtles and reef fishes or shrimps have been recorded only recently in the Southwest Atlantic (Sazima et al., 2004; pers. obs.), we believe that this is a widespread relationship that possibly went unrecognised as such by marine biologists. A turtle posing for a small cleaner near a rocky outcrop or under a ledge may well be regarded as a resting one (Fig. 3), as both the shelter and the turtle's postures in both situations are somewhat similar. Hawksbills commonly rest on the bottom and occasionally under ledges and in crevices both during the day and at night (per. obs.). However, a turtle being serviced at a cleaning station stretches its forelimbs and elevates its head and fore body. Thus, an attentive look may reveal that the turtle actually holds one of the characteristic postures assumed during cleaning interactions (Booth \& Peters, 1972; Losey et al., 1994; Sazima et al., 2004; this study), and a brief inspection under the ledge or near the outcrop will likely disclose a cleaner shrimp and/or fish working on the turtle.

The putative origin of cleaning symbiosis between hawksbill turtles and cleaner shrimps may follow simple behavioural steps: (1) in the reef habitat hawksbills usually remain or rest near rocky ledges, sometimes in a crevice or under a ledge (Fig. 3; see also Meylan \& Donnelly, 1999); (2) some of these rocks and ledges harbour stations tended by cleaning shrimps; (3) the shrimps treat the turtles as additional clients notwithstanding their differences in appearance and size when compared with fishes; (4) the turtles get rid of shed skin and epibionts, and receive tactile stimuli as well, both factors advantageous and/or pleasant for the turtles (Losey et al., 1994); (5) foraging turtles learn to seek the cleaning stations, and to pose for the shrimps to obtain the mentioned advantages. This scenario seems supported 


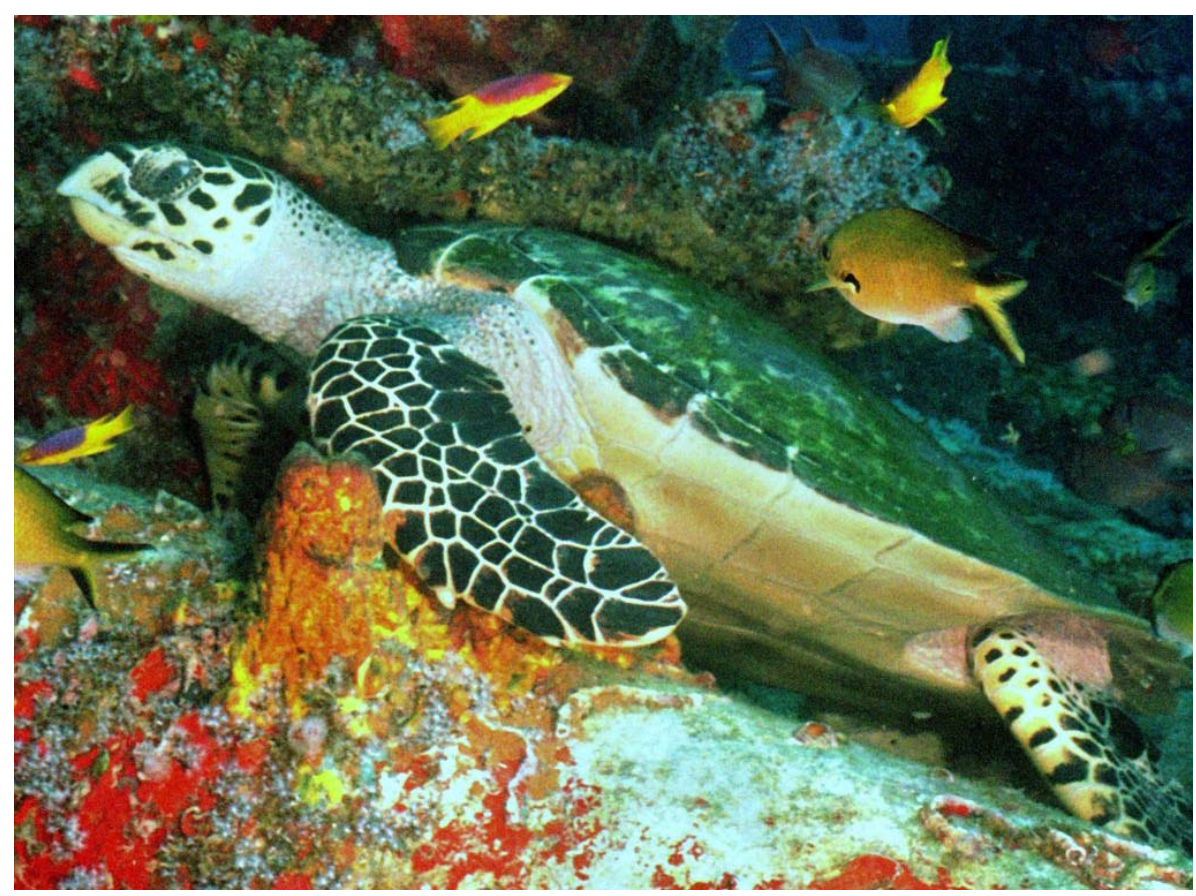

Fig. 3. A hawksbill turtle (Eretmochelys imbricata) characteristically positioned under a rocky ledge, a behaviour that may either indicate a resting episode or a cleaning interaction with shrimps.

both by studies on cleaning symbiosis between fishes, and between fishes and marine turtles (e.g., Losey, 1979; Losey et al., 1994; Côté, 2000; Sazima et al., 2004), being reminiscent of the presumptive origin of cleaning between reef sharks and cleaner gobies presented by Sazima and Moura (2000). The barber pole cleaner shrimp seems active mostly at night (Criales \& Corredor, 1977), and hawksbill turtles tend to wedge themselves in crevices and under ledges during night resting (AG and IS, pers. obs.), two additional events that lend further support to the above postulated origin.

\section{Acknowledgements.}

We thank the Projeto Tamar/Ibama, the Centro Golfinho Rotador (through J.M. Silva-Jr.), and the Ibama (through M.A. Silva) for logistical support; the Projeto Tamar/Ibama for permission to use figure 3; the Ibama for permission to study reef fishes at the National Marine Park of Fernando de Noronha; the CNPq, FAPESP and Fundação Pró-Tamar for essential financial support. We dedicate this paper to Thaisi M. Sanches (in memoriam) and Cláudio Bellini for their pioneering studies on marine turtles at the Fernando de Noronha Archipelago, and thus taking the first steps for creating the National Marine Park of Fernando de Noronha.
ALTMANN, J. 1974. Observational study of behavior: sampling methods. Behavior 49: 227-265.

BOOTH, J. \& PETERS, J. A. 1972. Behavioural studies on the green turtle (Chelonia mydas) in the sea. Anim. Behav. 20: 808-812.

CÔTÉ, I. M. 2000. Evolution and ecology of cleaning symbioses in the sea. In: Oceanography and Marine Biology: an Annual Review 38 (R. N. Gibson \& M. Barnes, eds.). Taylor and Francis, London, p. 311-355.

CRIALES, M. M. \& CORREDOR, L. 1977. Aspectos etologicos y ecologicos de camarones limpiadores de peces (Natantia: Palaemonidae, Hyppolytidae, Stenopodidae). An. Inst. Inv. Mar. - Punta Betín 9: 141156.

FRANCINI-FILHO, R. B. MOURA, R. L. \& SAZIMA, I. 1999. Simbiose de limpeza envolvendo peixes e camarões no Arquipélago de Fernando de Noronha, Pernambuco. Resumos XIII Encontro Brasileiro de Ictiologia, São Carlos: 137

FRANCINI-FILHO, R. B. MOURA, R. L. \& SAZIMA, I. 2000. Cleaning by the wrasse Thalassoma noronhanum, with two records of predation by its grouper client Cephalopholis fulva. J. Fish Biol., 56: 802-809.

HUMANN, P. 1996. Reef creature identification: Florida, Caribbean, Bahamas. New World Publications, Jacksonville.

\section{References}

http://www.biotaneotropica.org.br 
LEHNER, P.N. 1979. Handbook of ethological methods. Garland STPM Press, New York.

LIMBAUGH, C., PEDERSON, H., CHACE-Jr., F. A. 1961. Shrimps that clean fishes. Bull. Mar. Sci. Gulf \& Carib. 11:237-257.

LOSEY, G. S. 1979. Fish cleaning symbiosis: proximate causes of host behaviour. Anim. Behav. 27: 669-685.

LOSEY, G. S. 1993. Knowledge of proximate causes aids our understanding of function and evolutionary history. Mar. Behav. Physiol. 23: 175-186.

LOSEY, G. S., BALAZS, G. H. \& PRIVITERA, L. A. 1994. Cleaning symbiosis between the wrasse Thalassoma duperrey, and the green turtle Chelonia mydas. Copeia 1994: 684-690.

MAIDA, M. \& FERREIRA, B.P. 1997. Coral reefs of Brazil: an overview. Proc. Int. Coral Reef Symp. 8: 263-274.

MAIDA, M., FERREIRA, B.P. \& BELLINI, C. 1995. Avaliação preliminar do recife da Baía do Sueste, Fernando de Noronha, com ênfase nos corais escleractíneos. Bol. Téc. Cient. CEPENE 3: 37-47.

MEYLAN, A. B. \& DONNELLY, M. 1999. Status justification for listing the hawksbill turtle (Eretmochelys imbricata) as critically endangered on the 1996 IUCN Red List of Threatened Animals. Chelon. Conserv. Biol. 3:200-224.

SANCHES, T. M. \& BELLINI, C. 1999. Juvenile Eretmochelys imbricata and Chelonia mydas in the Archipelago of Fernando de Noronha, Brazil. Chelon. Conserv. Biol. 3: 308-311.

SAZIMA, C. , GROSSMAN, A., BELLINI, C.\& SAZIMA, I. 2004. The moving gardens: reef fishes grazing, cleaning, and following green turtles. Cybium 28(1): 47-53.

SAZIMA, I. \& MOURA, R. L. 2000. Shark (Carcharhinus perezi), cleaned by the goby (Elacatinus randalli), at Fernando de Noronha Archipelago, western South Atlantic. Copeia 2000: 297-299.

SAZIMA, I., MOURA, R. L., SAZIMA, C. 1999. Cleaning activity of juvenile angelfish, Pomacanthus paru, on the reefs of the Abrolhos Archipelago, Western South Atlantic. Env. Biol. Fish. 56: 399-407.

SMITH, S. H. 1988. Cleaning of the hawksbill turtle (Eretmochelys imbricata) by adult french angelfish (Pomacanthus paru). Herp. Review 19: 55.

VAN TASSEL, J. L., BRITO, A. \& BORTONE, S. A. 1994. Cleaning behavior among marine fishes and invertebrates in the Canary Islands. Cybium 18: 117-127.

WITZELL, W. N. 1983. Synopsis of the biological data on the hawksbill turtle Eretmochelys imbricata (Linnaeus, 1766). FAO Fish. Syn. 137: 1-78.

Title: Hawksbill turtles visit moustached barbers: cleaning symbiosis between Eretmochelys imbricata and the shrimp Stenopus hispidus

Authors: Ivan Sazima, Alice Grossman, Cristina Sazima

Biota Neotropica, Vol. 4( number 1): 2004

http://www.biotaneotropica.org.br/v4n 1/pt/ abstract?short-communication+BN01504012004

Date Received 01/21/2004-Revised 02/22/2004

Accepted 03/12/2004

ISSN 1676-0611 